\title{
Poziom wiedzy chorych w zakresie nadciśnienia tętniczego
}

The level of knowledge of patients in the field of hypertension

\author{
AGNIESZKA PIERNIKOWSKA ${ }^{1}$, ANNA PIOTROWSKA ${ }^{2}, \quad$ ANNA \\ MIZIEWICZ3 \\ ${ }^{1}$ Instytut Nauk o Zdrowiu, Państwowa Uczelnia Zawodowa we Włocławku Wojewódzki \\ Szpital Specjalistyczny we Włocławku, Oddział Chorób Wewnętrznych i Nefrologii \\ ${ }^{2}$ Instytut Nauk o Zdrowiu, Państwowa Uczelnia Zawodowa we Włocławku Wojewódzki \\ Szpital Specjalistyczny we Włocławku, Oddział Dziecięcy \\ ${ }^{2}$ Instytut Gruźlicy i Chorób Płuc w Warszawie
}

DOI: https://dx.doi.org/10.21784/lwP.2019.020

ISSN: 2451-1846

\section{Streszczenie:}

Wstęp. Według danych (WHO) Światowej Organizacji Zdrowia nadciśnienie tętnicze należy do największych globalnych zagrożeń zdrowotnych zaliczanych do chorób cywilizacyjnych. Odsetek osób cierpiących na nadciśnienie tętnicze rośnie szybciej niż populacja naszego globu, co powoduje, że liczba osób z nadciśnieniem tętniczym wciąż wzrasta. Szacuje się, że w 2025 roku liczba osiągnie 1, 56 mld, co stanowić będzie 29\% ludności [1]. Nadciśnienie tętnicze rozpoznajemy wówczas, gdy w trakcie co najmniej dwóch wizyt u lekarza podczas kilku pomiarów ciśnienia tętniczego jedna z jego wartości jest równa lub przekracza 140/90 mmHg [2].

Cel. Celem pracy jest zbadanie poziomu wiedzy i umiejętności pacjentów z nadciśnieniem tętniczym w zakresie samoopieki.

Materiał i metody. Materiał badawczy uzyskano za pomocą sondażu diagnostycznego. Natomiast jako narzędzie wykorzystano kwestionariusz ankiety składający się z metryczki oraz części głównej badającej poziom wiedzy i umiejętności chorych $\mathrm{z}$ nadciśnieniem tętniczym w zakresie 
samoopieki. Kwestionariusz ankiety zawierał 20 pytań i były to pytania w formie zamkniętej. Badania przeprowadzono w okresie od maja do czerwca 2017 roku na Oddziale Kardiologii Specjalistycznego Szpitala Wojewódzkiego w Ciechanowie. W badaniu uczestniczyło 100 pacjentów Oddziału Kardiologii, przy czym każdy uczestnik był osobą pełnoletnią. Respondenci otrzymali informacje dotyczące zasad wypełnienia kwestionariusza ankiety a także zapewnienie o anonimowości zebranych danych.

Wyniki. Według opinii respondentów okazało się, że odpowiedzi pacjentów na pytania dotyczące wiedzy i umiejętności chorych z nadciśnieniem tętniczym w zakresie samoopieki: $46 \%$ ankietowanych prezentuje wiedzę na średnim poziomie, $28 \%$ to osoby, których wiedza jest na niskim poziomie. zaś wysoki poziom wiedzy wykazuje tylko $26 \%$ ankietowanych. Zatem okazuje się, że poziom wiedzy w badanej grupie jest średni i nie wykazuje związku pomiędzy wiekiem, płcią, czy stanem cywilnym.

Wnioski. Celem działań prewencyjnych jest uświadomienie społeczeństwu, jak przeciwdziałać chorobie, w jaki sposób żyć, sprawować samodzielnie kontrolę nad pomiarami ciśnienia tętniczego krwi, aby nie dopuścić do powikłań.

\title{
Słowa kluczowe: nadciśnienie tętnicze, samoopieka, wiedza
}

\begin{abstract}
:
Introduction. WHO data suggest that hypertension is the greatest health threat and one of the most significant civilisation diseases. The percentage of people suffering form arterial hypertension is rising faster than the world's population. Thus the number of people with arterial hypertension continues to increase. It is estimated that by 2025 the number of sufferes will have reached 1,56 billion, which will represent $29 \%$ of the world's population[1]Arterial hypertension can only be confirmed when at three consecutive medical visits, BP measurements show raised values, that is when $\mathrm{BP}$ is equal or higher than $140 / 90 \mathrm{mmHg}$ [2].
\end{abstract}

Aim. The aim of the study is to measure the level of patients knowledge about arterial hypertension and their skills in the area of self-care. 
Material and methods. The diagnostic survey method was used. The questionnaire was used as a tool. It consisted of 20 close-ended questions devoted to patients' knowledge about arterial hypertension and their skills in self-care. The study was carried out from May to June 2017 in Department of Cardiology of the Specialist Hospital in Ciechanów. The study included 100 patients form Department of Cardiology and each of them was a person of age. Respondents were informed about rules on filling in the questionnaire and the fact that data were rendered anonymous for statistical purposes

Results. According to respondents the knowledge about arterial hypertension and their skills in the area of self-care : the knowledge of $46 \%$ of respondents remains on an average level, 28\% respondents present knowledge on a low level. Only $26 \%$ of respondents show a high level of knowledge. It turns out that the knowledge about arterial hypertension and respondents' skills in self-care are on an average level. The study also showed that there is no relationship among age, sex and education.

Conclusion. The purpose of preventing meassures is to make people aware how they may prevent the disease, live and monitor their blood preassure meassurements in order to avoid complications.

Keywords: arterial hypertension, self-care, knowledge

\section{Wstęp}

Na rozwój nadciśnienia tętniczego ma wpływ wiele czynników, ale także na powikłania układu sercowo-naczyniowego w późniejszym okresie choroby. Jednym z głównych czynników ryzyka wyróżniamy otyłość. Przyrost masy ciała nawet o $1 \mathrm{~kg}$ powoduje wzrost ryzyka zachorowania na nadciśnienie tętnicze nawet o $5 \%$. Zwiększenie masy ciała o $10 \%$ wywołuje wzrost skurczowego ciśnienia tętniczego o $6 \mathrm{mmHg}$, natomiast rozkurczowego o $4 \mathrm{mmHg}$ [2]. Kolejnym czynnikiem jest nadmierna ilość sodu w codziennej diecie. Poprzez jego nadmierne spożycie zwiększa się objętość płynów ustrojowych co prowadzi do wzrostu ciśnienia tętniczego. Osoby spożywające duże ilości alkoholu obciążone są występowaniem wyżej wymienionej 
jednostki chorobowej. Nawet jednorazowe nadmierne spożycie alkoholu prowadzi do wzrostu ciśnienia. Palenie tytoniu również negatywnie wpływa na pracę serca oraz uszkadza ściany naczyń krwionośnych co sprzyja występowaniu miażdżycy. Do czynników ryzyka zaliczamy również stres czy niedostateczną ilość snu [3].

Ze względu na działanie tych różnorodnych czynników, nadciśnienie dzielimy na pierwotne, które jest wynikiem działania różnorodnych czynników zarówno genetycznych jak i środowiskowych oraz wtórne. Zatem patogeneza jest wieloczynnikowa a jednoznaczna przyczyna nie zawsze znana, gdyż jednocześnie wiele czynników może zaburzać prawidłowe działanie układów, które są odpowiedzialne za utrzymanie prawidłowych wartości ciśnienia tętniczego [4]. Nadciśnienie to najczęściej ma przebieg bezobjawowy, jednakże mogą występować bóle głowy, łatwe męczenie się czy zaburzenia snu [5]. Nadciśnienie pierwotne stanowi około 95 \% przypadków rozpoznanego nadciśnienia tętniczego. Z kolei nadciśnienie wtórne stanowi około 5\% rozpoznawanej choroby nadciśnieniowej. A przyczynami wyżej wymienionej jednostki chorobowej są choroby miąższowe nerek, zwyrodnienie wielotorbielowate nerek, ostre i przewlekłe zapalenie kłębuszków nerkowych, wodonercze, choroby tętnic nerkowych, zwężenie tętnicy nerkowej, zapalenie naczyń wewnątrznerkowych $\stackrel{1}{1}$, choroby nadnerczy, hiperaldosteronizm pierwotny wywołany gruczolakiem lub przerostem nadnerczy, guz chromochłonny czy zespół Cushinga, choroby tarczycy, nadczynność przytarczyc. Zwiększone ciśnienie wewnątrzczaszkowe, guz mózgu, uraz mózgu, choroby układu krążenia, koarktacja aorty, nadciśnienie wywołane ciążą, zespół obturacyjnego bezdechu sennego, ostry stres, hiperwolemia. Leki egzogenne hormony (estrogeny, kortykosteroidy, erytropoetyna, sympatykomimetyki, cyklosporyna, inhibitory MAO) substancje toksyczne: amfetamina, kokaina, metale ciężkie [6]. 
Innowacje w Pielęgniarstwie i Naukach o Zdrowiu

$4(4) / 2019$

Metody leczenia nadciśnienia tętniczego obejmują farmakoterapię, ale przede wszystkim zmianę stylu życia. Leczenie chorych z nadciśnieniem tętniczym ma na celu normalizację wartości BP a także minimalizację ryzyka sercowo - naczyniowegoํㅗ. Dlatego istotnym aspektem jest nie tylko obniżenie ciśnienia tętniczego czy leczenie powikłań narządowych, ale głównie modyfikacja czynników ryzyka, takich jak: palenie tytoniu, zaburzenia lipidowe czy otyłość [7].

Metodę stosowanego leczenia ustala się indywidualnie dla każdego pacjenta na podstawie wartości ciśnienia tętniczego, po uprzednim ustaleniu jego przyczyny a także po ocenie możliwych powikłań sercowo-naczyniowych a także chorób współistniejących [4]. Rozpoznanie nadciśnienia tętniczego opiera się na pomiarach ciśnienia tętniczego krwi podczas wizyty pacjenta w gabinecie lekarskim lub poprzez przeprowadzenie całodobowego ambulatoryjnego pomiaru ciśnienia tętniczego, w którym określa się kontrolę wartości ciśnienia tętniczego co 15-20 minut w ciągu dnia oraz co 30 minut w nocy [8].

Wyniki odczytuje się $\mathrm{z}$ danych $\mathrm{z}$ rejestratora dzięki odpowiednim programom komputerowym. Rezultat ma na celu ukazanie średnich oraz maksymalnych wartości ciśnienia oraz uzyskanie informacji na temat dobowej zmienności ciśnienia tętniczego, nocnych spadków jego wartości, wzrost wartości ciśnienia w godzinach porannych czy też rozpoznanie nadciśnienia białego fartucha czy nadciśnienia maskowanego (ukrytego) [9].

\section{Cel}

Celem pracy jest zbadanie poziomu wiedzy i umiejętności pacjentów z nadciśnieniem tętniczym w zakresie samoopieki. 


\section{Materiał i metody}

Badaniami objęto 100 pacjentów w Oddziale Kardiologii Specjalistycznego Szpitala Wojewódzkiego w Ciechanowie. Procedura badawcza obejmowała wszystkich uczestników pełnoletnich, respondenci otrzymali informacje dotyczące zasad wypełnienia kwestionariusza ankiety a także zapewnienie o anonimowości zebranych danych.

\section{Wyniki}

Według analizy otrzymanych wyników stwierdzono, iż w badaniu uczestniczyło $52 \%$ kobiet i $48 \%$ mężczyzn.

Tab.1. Płeć respondentów

\begin{tabular}{|l|l|l|}
\hline Płeć & Częstość & Procent \\
\hline kobieta & 52 & 52 \\
\hline mężczyzna & 48 & 48 \\
\hline Ogółem & 100 & 100 \\
\hline
\end{tabular}

Źródło: Wyniki badań własnych

Tab.2. Wiek respondentów

\begin{tabular}{|l|l|l|}
\hline Wiek & Częstość & Procent \\
\hline 41-55 lat & 36 & 36 \\
\hline 56-70 lat & 48 & 48 \\
\hline 71-85 lat & 16 & 16 \\
\hline Ogółem & 100 & 100 \\
\hline
\end{tabular}

Źródło: wyniki badań własnych 
Z uzyskanych badań wynika, iż wśród najliczniejszych grup uczestników stanowiły osoby w wieku 56-70lat (48\%), (36\%) to osoby w wieku 41-55 lat. Najmniej liczną grupę stanowiły osoby w przedziale wiekowym 71-85 lat (16\%).

Tab.3. Stan cywilny respondentów

\begin{tabular}{|l|l|l|}
\hline Stan cywilny & Częstość & Procent \\
\hline \hline wolny & 38 & 38 \\
\hline w związku & 62 & 62 \\
\hline Ogółem & 100 & 100 \\
\hline
\end{tabular}

Źródło: wyniki badań własnych

Wykazano, że $62 \%$ badanych stanowiły osoby w związku. Pozostałe $38 \%$, to osoby wolne. Badanie przeprowadzono w Oddziale Kardiologii Specjalistycznego Szpitala Wojewódzkiego w Ciechanowie, w obecności osoby przeprowadzającej badanie. Nie wszyscy z pacjentów wyrazili chęć wypełnienia ankiety. W czasie trwania całego okresu przeprowadzania badania 20 osób odmówiło udziału w badaniu. Rozdano 120 ankiet, uzyskując 109 ankiet. Ze względu na złe wypełnienie niektórych $\mathrm{z}$ ankiet, bądź brak odpowiedzi na pytania zaistniała konieczność odrzucenia kolejnych 9 ankiet. Podsumowując, powyższym do analizy zakwalifikowano 100 kwestionariuszy.

Aby zbadać poziom wiedzy respondentów zapytano respondentów badania o zdefiniowanie granicznej wartości ciśnienia tętniczego. W celu weryfikacji wiedzy pacjentów w tym zakresie, użyto pytań jednokrotnego wyboru, a wyniki przedstawiono w Tabeli nr 4. 
Tab.4. Prawidłowe określenie dla granicznej wartości ciśnienia tętniczego

\begin{tabular}{|l|l|l|}
\hline $\begin{array}{l}\text { Proszę podać prawidłowe określenie dla } \\
\text { granicznej wartości ciśnienia tętniczego }\end{array}$ & Częstość & Procent \\
\hline prawidłowe wartości ciśnienia tętniczego & 22 & 22 \\
\hline \hline $\begin{array}{l}\text { wartości ciśnienia tętniczego, powyżej } \\
\text { których rozpoznaje się nadciśnienie tętnicze }\end{array}$ & 51 & 51 \\
\hline $\begin{array}{l}\text { wartości ciśnienia tętniczego wskazujące na } \\
\text { wzmożone ryzyko wystąpienia zawału } \\
\text { mięśnia sercowego i udaru }\end{array}$ & 22 & 22 \\
\hline \hline $\begin{array}{l}\text { nieprawidłowe wartości ciśnienia } \\
\text { tętniczego }\end{array}$ & 5 & 5 \\
\hline \hline Ogółem & 100 & 100 \\
\hline
\end{tabular}

Źródło: wyniki badań własnych

$\mathrm{Z}$ analizy zamieszczonych odpowiedzi wynika, że nieznaczna większość ankietowanych (51\%), na zadane pytanie wskazała na odpowiedź - wartości ciśnienia tętniczego, powyżej których rozpoznaje się nadciśnienie tętnicze, tym samym udzielając poprawnej odpowiedzi. Na drugim miejscu z taką samą liczbą procentową (22\%) plasują się odpowiedzi, iż są to prawidłowe wartości ciśnienia a także wartości ciśnienia wskazujące na wzmożone ryzyko powikłań sercowo-naczyniowych. $5 \%$ osób ankietowanych wskazuje nieprawidłowe wartości ciśnienia tętniczego. 
Tab.5. Graniczne wartości ciśnienia tętniczego

\begin{tabular}{|l||l|l|}
\hline $\begin{array}{l}\text { Które z poniższych danych } \\
\text { przedstawiają graniczne } \\
\text { wartości ciśnienia tętniczego? }\end{array}$ & Częstość & Procent \\
\hline \hline $100 / 60 \mathrm{mmHg}$ & 10 & 10 \\
\hline \hline $120 / 80 \mathrm{mmHg}$ & 32 & 32 \\
\hline \hline $140 / 90 \mathrm{mmHg}$ & 47 & 47 \\
\hline \hline $150 / 90 \mathrm{mmHg}$ & 11 & 11 \\
\hline \hline Ogółem & 100 & 100 \\
\hline
\end{tabular}

Źródło: wyniki badań własnych

Z analizy pytań zawartych w autorskim kwestionariuszu ankiety wynika, że aż $53 \%$ ankietowanych nie zna granicznych wartości ciśnienia tętniczego, natomiast pozostałe 47\% znało poprawną odpowiedź na zadane pytanie.

\section{Tab.6. Zmiany stylu życia osób z nadciśnieniem tętniczym}

\begin{tabular}{|l|l|l|}
\hline $\begin{array}{l}\text { Jakie według Pani / Pana zmiany należy wprowadzić w } \\
\text { stylu życia osób z nadciśnieniem tętniczym aby poprawić } \\
\text { stan zdrowia i zmniejszyć ryzyko możliwych powikłań? }\end{array}$ & N & Procent \\
\hline redukcja masy ciała u osób z nadwagą i otyłością & 75 & $16,80 \%$ \\
\hline rzucenie palenia tytoniu & 85 & $19,10 \%$ \\
\hline zaprzestanie spożywania alkoholu & 77 & $17,30 \%$ \\
\hline \hline ograniczenie używania soli kuchennej w codziennej diecie & 76 & $17,00 \%$ \\
\hline zwiększenie aktywności fizycznej & 65 & $14,60 \%$ \\
\hline ograniczenie poziomu stresu & 68 & $15,20 \%$ \\
\hline
\end{tabular}

Źródło: wyniki badań własnych 
Istotną kwestią przeprowadzonego badania jest zmiana stylu życia dla poprawy stanu zdrowia. Wszystkie ze wskazanych odpowiedzi były poprawne, jednakże nie wszyscy badani wskazywali jednoznacznie na możliwe warianty. Za pomocą autorskiego kwestionariusza ankiety zbadano również umiejętności w zakresie samoopieki na podstawie posiadania własnego aparatu do pomiaru ciśnienia tętniczego krwi. Wyniki przedstawiono w poniżej w tabelach.

Tab.7. Aparat do pomiaru ciśnienia tętniczego

\begin{tabular}{|l|l|l|}
\hline $\begin{array}{l}\text { Czy posiada Pani / Pan } \\
\text { własny aparat do pomiaru } \\
\text { ciśnienia tętniczego? }\end{array}$ & Częstość & Procent \\
\hline \hline TAK & 68 & 68 \\
\hline NIE & 32 & 32 \\
\hline \hline Ogółem & 100 & 100 \\
\hline
\end{tabular}

Źródło: wyniki badań własnych

$68 \%$ pacjentów posiada własny aparat do pomiaru ciśnienia tętniczego. Pozostałe $32 \%$ nie posiada aparatu

Tab.8. Znajomość prawidłowej techniki pomiaru ciśnienia tętniczego krwi

\begin{tabular}{|l|l|l|}
\hline $\begin{array}{l}\text { 5.Czy zna Pani/Pan prawidłową } \\
\text { technikę pomiaru ciśnienia } \\
\text { tętniczego krwi? }\end{array}$ & Częstość & Procent \\
\hline TAK & 58 & 58 \\
\hline \hline NIE & 42 & 42 \\
\hline Ogółem & 100 & 100 \\
\hline
\end{tabular}

Źródło: wyniki badań własnych 
Dysonans pomiędzy uczestnikami badania, którzy znają technikę pomiaru ciśnienia a tymi, którzy jej nie znają jest nieznaczna, biorąc pod uwagę, iż 58\% osób stwierdza, znajomość techniki poprawnego pomiaru ciśnienia tętniczego krwi.

Tab.9. Częstość wykonywania pomiaru ciśnienia tętniczego

\begin{tabular}{|l|l|l|}
\hline $\begin{array}{l}\text { Jak często wykonuje Pani/Pan pomiar } \\
\text { ciśnienia tętniczego? }\end{array}$ & Częstość & Procent \\
\hline \hline codziennie & 19 & 19 \\
\hline raz w tygodniu & 16 & 16 \\
\hline raz w miesiącu & 12 & 12 \\
\hline gdy źle się czuję & 53 & 53 \\
\hline Ogółem & 100 & 100 \\
\hline
\end{tabular}

Źródło: wyniki badań własnych

Nieodłącznym elementem dla osiągnięcia pożądanych efektów leczenia jest regularne wykonywanie pomiarów ciśnienia tętniczego w domu. Na tle przeprowadzonych badań wykazano, że zachowania te nie są zgodne z zaleceniami, ponieważ ponad połowa badanych dokonuje pomiaru tylko w momencie złego samopoczucia.

Tab.10. Książeczka kontroli ciśnienia tętniczego

\begin{tabular}{|l|l|l|}
\hline $\begin{array}{l}\text { Czy prowadzi Pani/Pan książeczkę } \\
\text { kontroli ciśnienia tętniczego? }\end{array}$ & Częstość & Procent \\
\hline TAK & 32 & 32 \\
\hline NIE & 68 & 68 \\
\hline Ogółem & 100 & 100 \\
\hline
\end{tabular}

Źródło: wyniki badań własnych 
Z powyższych danych wynika, że $68 \%$ badanych nie prowadzi książeczki kontroli ciśnienia tętniczego.

Kwestionariusz ankiety zawierał także zagadnienia w zakresie sytuacji stresowych, poproszono respondentów o to, by wskazali jak radzą sobie ze stresem. U 29\% badanych sytuacje stresowe występują często, u 64\% sytuacje takie zdarzają się rzadko, natomiast $7 \%$ twierdzi że takie sytuacje u nich nie występują. Z wyników dowiadujemy się, że $45 \%$ badanych radzi sobie średnio w sytuacjach stresowych, $33 \%$ radzi sobie dobrze. $16 \%$ radzi sobie słabo, a $6 \%$ przyznaje, że nie radzi sobie wcale.

W Tabeli $\mathrm{nr}$ 11, przeanalizowano poziom wiedzy i umiejętności chorych $\mathrm{z}$ nadciśnieniem tętniczym $\mathrm{w}$ zakresie samoopieki. Z badań tych wynika, że $46 \%$ ankietowanych prezentuje wiedzę na średnim poziomie, $28 \%$ to osoby, których wiedza jest na niskim poziomie, natomiast tylko $26 \%$ wykazuje wysoki poziom wiedzy.

Tab.11.Poziom wiedzy badanych osób

\begin{tabular}{|l|l|l|}
\hline $\begin{array}{l}\text { Poziom wiedzy i umiejętności chorych z } \\
\text { nadciśnieniem tętniczym w zakresie samoopieki. }\end{array}$ & Częstość & Procent \\
\hline NISKI POZIOM WIEDZY & 28 & 28 \\
\hline ŚREDNI POZIOM WIEDZY & 46 & 46 \\
\hline WYSOKI POZIOM WIEDZY & 26 & 26 \\
\hline \hline Ogółem & 100 & 100 \\
\hline
\end{tabular}

Źródło: wyniki badań własnych

\section{Dyskusja}

Bardzo ważne jest, aby zachęcać pacjenta do samodzielnych pomiarów wartości ciśnienia tętniczego $\mathrm{w}$ domu i do odnotowania 
wyników w dzienniczku samokontroli. U pacjentów, którzy kontrolują wartości BP w domu spada ryzyko wystąpienia reakcji białego fartucha i dlatego można lepiej ocenić efekty leczenia oraz dokładniej określić korelację z ryzykiem sercowo-naczyniowym. Jednakże warto wspomnieć, iż jest to tylko działanie uzupełniające cały proces terapeutyczny i nie może stanowić jedynej metody kontroli ciśnienia tętniczego krwi [9].

Mobilizacja pacjenta do samokontroli i obserwacji niepokojących objawów tworzy spójną całość w procesie terapeutycznym poprzez włączenie chorego do procesu leczniczego $\mathrm{w}$ nawiązaniu do samokontroli pacjenta $\mathrm{w}$ domu. Ważnym jest przygotowanie oraz poinformowanie chorego o prawidłowości i wykonywaniu poszczególnych czynności podczas samodzielnych pomiarów ciśnienia tętniczego krwi [10]. Zmiana stylu życia dotyczy również pacjentów przyjmujących leki hipotensyjne.

Bardzo ważnym jest, aby chorzy na nadciśnienie tętnicze przestrzegali zasad zdrowego odżywiania. Należy wprowadzić dietę, która zmierza do redukcji masy ciała, gdyż otyłość wpływa niekorzystnie na przebieg choroby i stanowi dodatkowe obciążenie dla serca, które musi dostarczyć krew do nagromadzonej tkanki tłuszczowej. U pacjentów z otyłością w nadciśnieniu tętniczym należy wprowadzić dietę ubogoenergetyczna [11]. Ważnym elementem w codziennej diecie jest odpowiednie spożycie owoców i jarzyn a także ograniczenie ilości sodu w przygotowywanych potrawach a bogatych w potas poprzez zwiększenie spożycia warzyw i innych pokarmów pochodzenia roślinnego, 4-5 porcji. Nie bez znaczenia jest również ograniczanie produktów o dużej zawartości tłuszczów zwierzęcych, które należy zastąpić rybami oraz innymi produktami zawierającymi nienasycone kwasy tłuszczowe [11].

Bezwzględnym warunkiem odpowiedniej terapii leczenia nadciśnienia tętniczego krwi jest zaprzestanie palenia oraz 
ograniczenie spożycia alkoholu do $30 \mathrm{ml}$ etanolu na dobę. U kobiet oraz osób szczupłych dawkę dopuszczalną należy zmniejszyć o połowę gdyż w przeciwieństwie do mężczyzn kobiety wchłaniają więcej etanolu z przewodu pokarmowego, natomiast osoby szczupłe są bardziej podatne na jego działanie [12].

Ponadto spożycie kofeiny może wywierać wpływ hipertensyjny, jednakże tolerancja każdego człowieka na działanie kofeiny jest inna, więc ilość jej przyjmowania i wrażliwość na nią $\mathrm{u}$ danego pacjenta powinna być ustalana indywidualnie [13].

Niebagatelny wpływ na rozwój choroby oraz podwyższenie BP ma również stres a także niedostateczna ilość snu. Jeżeli to możliwe, pacjenci i w tym wypadku powinni dokonać zmian poprzez eliminację czynników stresogennych a także zadbanie o odpowiednią ilość snu [14].

Najważniejszym $\quad \mathrm{z}$ elementów postępowania niefarmakologicznego jest uświadomienie pacjentowi jego znaczenia, pozytywnego wpływu samoopieki oraz poinformowanie o konieczności stosowania się do zaleceń dla utrzymania oczekiwanych efektów terapii.

\section{Wnioski}

1. Nie wykazano korelacji pomiędzy płcią ankietowanych a ich poziomem wiedzy i umiejętności w zakresie samoopieki.

2. Nie wykazano korelacji pomiędzy wiekiem ankietowanych a ich poziomem wiedzy i umiejętności w zakresie samoopieki.

3. Wykazano korelację pomiędzy stanem cywilnym ankietowanych a ich poziomem wiedzy i umiejętności w zakresie samoopieki. Ponad 53\% badanych będących w związku wykazuje średni poziom wiedzy.

4. Zalecenia dla praktyki pielęgniarskiej 
Zadaniem pielęgniarki jest edukowanie pacjentów na temat redukcji masy ciała $\mathrm{w}$ przypadku nadwagi bądź otyłości, a więc również nauka doboru odpowiednich produktów w jadłospisie, prowadzenie dzienniczków samokontroli, wyjaśnienie zasad prawidłowej techniki pomiaru ciśnienia tętniczego krwi, jak również nauka samodzielnych jego pomiarów, wyjaśnienie szkodliwości palenia tytoniu oraz spożywania alkoholu.

Przeprowadzone badania w bardzo dogłębny sposób przedstawiają problem poziomu wiedzy chorych na temat nadciśnienia tętniczego $\mathrm{w}$ zakresie samoopieki, w których udowodniono, iż metody leczenia nadciśnienia tętniczego obejmują nie tylko farmakoterapię, ale przede wszystkim zmianę stylu życia. Leczenie chorych z nadciśnieniem tętniczym ma na celu normalizację wartości ciśnienia tętniczego krwi, dlatego istotnym aspektem jest obniżenie ciśnienia, a więc modyfikacja również czynników ryzyka, takich jak: zaburzenia lipidowe czy otyłośćć, przygotowanie chorego do samoopieki.

\section{Bibliografia / Bibliography:}

1. Pruszczyk P., Hryniewiecki T., Drożdż J. Wielka Interna. Kardiologia część II z elementami angiologii. Wydawnictwo Medical Tribune Polska. Warszawa, 2010;488-509.

2. Biała B., Cicha M. Nadciśnienie tętnicze. Magazyn Pielęgniarki i Położnej, 2011;14.

3. Budaj A., Leśniak W. Interna Szczeklika. Wydawnictwo Medycyna Praktyczna, Kraków 2017.

4. Kaszuba D., Nowicka A. Pielęgniarstwo kardiologiczne. Podręcznik dla studiów medycznych. Wydawnictwo Lekarskie PZWL. Warszawa, 2011;158-167. 
5. Skrzypiec - Spring M., Chlebda E., Spring A., Skrzypiec D., Cerwid - Ląd A., Trocha M., Szumny D., Szeląg A. Nadciśnienie tętnicze - od rozpoznania do leczenia. Część I - diagnostyka i klasyfikacja nadciśnienia tętniczego. Przewodnik Lekarza 2005;4:28-34.

6. Kosiński P., Dobrowolski P. Nadciśnienie wtórne - przyczyny, diagnostyka, leczenie. Kardiologia na co dzień 2008;3,1:25-30.

7. Januszewicz A., Prejbisz A. Nadciśnienie tętnicze, problemy współczesnej terapii w praktyce klinicznej, Medycyna Praktyczna, Kraków, 2015;75.

8. Więcek A., Nieszporek T. Postępy w nefrologii i nadciśnieniu tętniczym, tom XIII, Medycyna Praktyczna, Kraków 2014;35.

9. Prejbisz A., Januszewicz A., Januszewicz W. Nadciśnienie tętnicze postępy 2015. Medycyna Praktyczna 2016;4.

10. Kucharska W., Wilczewska L., Skrzypek - Czerko M. Rola pielęgniarki w ograniczeniu czynników ryzyka nadciśnienia tętniczego na podstawie doświadczeń $\quad$ Regionalnego Centrum NT w Gdańsku. Problemy pielęgniarstwa, 2009;17.

11. Frank M., Campos H. Leczenie dietą w nadciśnieniu tętniczym. Kardiologia po Dyplomie, 2010;9(10).

12. Głuszek J., Kosicka T. Wpływ kawy, herbaty, kakao na ciśnienie tętnicze i układ sercowo - naczyniowy. Nadciśnienie Tętnicze 2014;18,1:1-8.

13. Januszewicz W., Sznajderman M. Jak żyć z nadciśnieniem tętniczym. Wydawnictwo Lekarskie PZWL, Warszawa 2008; 61-73.

14. Jodłowska E., Juszczak M. Wpływ stresu przewlekłego na rozwój nadciśnienia tętniczego. Folia Medica Lodziensia, 2013;40(1):53.

Otrzymano: 05.03.2019r. 
Innowacje w Pielęgniarstwie i Naukach o Zdrowiu

$4(4) / 2019$

Zaakceptowano: 11.04.2019.

22250 znaków 